\title{
Pengaruh Guided Inquiry Learning terhadap Hasil Belajar Matematika Siswa di SD Inpres 103 HBM Kota Sorong
}

\author{
Cindi Nuryanti Aynufa ${ }^{1}$, Alman $^{2} \&$ Heny Sri Astutik ${ }^{3}$
}

\author{
Prodi PGSD, Universitas Pendidikan Muhammadiyah Sorong, Indonesia \\ ${ }^{3}$ Prodi Pend. Matematika, Universitas Pendidikan Muhammadiyah Sorong, Indonesia \\ $\bowtie$ E-mail: aynufacindi@gmail.com
}

\begin{abstract}
Abstrak
Penelitian ini bertujuan untuk mengetahui pengaruh penggunaan guided inquiry learning terhadap hasil belajar matematika siswa pada materi operasi pecahan.Metode yang digunakan dalam penelitian ini adalah metode pra eksperimen dengan desain penelitian One Shot Case Study Design.Data menunjukkan rata-rata skor observasi guru (peneliti) dan siswa sebesar 100\% dengan kriteria sangat baik. Hasil analisis ketuntasan belajar pada nilai rata - rata posttest 76,78.uji normalitas hasil belajar posttest memiliki taraf signifikansi $0,121>0,05$. Uji -t test one sample t testhasil posttest berdasarkan hasil perhitungan maka diperoleh $\mathrm{t}_{\text {hitung }}$ sebesar 8.953 dengan $\mathrm{dk}=\mathrm{n}-1(28-1=27)$ diperoleh $\mathrm{t}_{\text {tabel }}$ sebesar1.915. Berdasarkan hasil analisis data yaitu nilai $t_{\text {hitung }}>t_{\text {tabel }}(8.953>1.703)$, dengan besarnya taraf signifikansi 0.05 , yakni $(0.000<0.05)$ maka Hipotesis diterima, Dengan demikian dapat disimpulkan bahwa terdapat pengaruh guided inquiry learning terhadap hasil belajar matematika siswa pada materi operasi pecahan di kelas III SD Inpres 103 HBM Kota Sorong.
\end{abstract}

Kata Kunci: Guided Inquiry Learning; Hasil Belajar Matematika; Operasi Pecahan.

\begin{abstract}
This study alms to determine the effect of the use of guided inquiry learning on student learning outcomes in mathematical operations material. The method used in this study is a pre-experimental method with the research design one shot case study design. Data shows the average abservation score of teachers ( researchers) and students equal to $100 \%$ with very good criteria. The results of analysis of learning completeness at an average value of 76.78 posttest normalitytest posttest learning outcomes have a significance level of 0,121 >0,05. T-test one sample t test posttest results based on the calculation results obtained taitung of 8,953 with $d k=n-1(28-1=27)$ obtained a table of 1,915. Based on the results of data analysis namely tcount > table (8,953 > 1,703), With a significance level of 0,05 , i. e. inquiry learning effect on students' mathematics lesrning outcomes in fraction operating material at class III SD Inpres 103 HBM Sorong City.
\end{abstract}

Keywords: Guided Inquiry Learning; Mathematics Learning Outcomes; Operasi Pecahan. 


\section{PENDAHULUAN}

Matematika merupakan salah satu mata pelajaran yang telah diberikan mulai dari tingkat sekolah dasar. Opearsi Pecahan tidak pernah lepas dari operasi hitung baik penjumlahan, pengurangan, perkalian maupun pembagian dengan menggunakan materi pecahan telah diterapkan pada siswa dalam kehidupan sehari-hari, hanya saja siswa kurang memahami mengenai konsep pecahan, oleh karena itu masih banyak siswa yang salah dalam mengerjakan dan memecahkan masalah soal-soal pada materi pecahan. Hal tersebut Sejalan dengan (Alman, 2015) menjelaskan bahwa materi pembelajaran matematika di Sekolah Dasar menekankan pada pemahaman konsep. Selain itu juga (Alman, 2015) melanjutkan penjelasannya bahwa materi matematika merupakan materi yang berikan penekanan pada penanaman konsep, kemudian pemahaman konsep serta keterampilanketerampilan agar peserta didik memiliki kemampuan dalam memecahkan masalah. Guru yang secara langsung terlibat dalam proses belajar mengajar memegang peranan penting dalam menentukan hasil belajar yang akan dicapai oleh siswa. Salah satu diantaranya adalah kemampuan siswa menyelesaikan soal-soal matematika pecahan.

Sofiana, (2015) mengatakan bahwa hasil belajar merupakan hasil dari suatu interaksi tindak belajar dan tindak mengajar. Dari sisi guru, tindak mengajar diakhiri dengan proses evaluasi hasil belajar. Dari siswa, hasil belajar merupakan puncak proses belajar yang merupakan bukti dari usaha yang telah dilakukan. Dari sisi guru, tindak mengajar diakhiri dengan proses evaluasi hasil belajar. Dari siswa, hasil belajar merupakan puncak proses belajar yang merupakan bukti dari usaha yang telah dilakukan. informasi yang diberikan oleh guru secara maksimal.

Berdasarkan hasil observasi dan wawancara dengan guru kelas III A di SD Inpres 103 HBM Kota Sorong penguasaan pelajaran matematika materi operasi pecahan masih banyak mengalami kesulitan salah satu kesulitannya dalam mengoperasikan bentukbentuk pecahan kedalam bentuk pecahan sederhana karena masih banyak siswa yang mengalami kesulitan sehingga hasil belajarnya menjadi rendah, hal ini dapat dilihat dari nilai siswa. Berdasarkan daftar nilai siswa kelas III tahun ajaran 2018/2019 semester 1 bahwa nilai rata-rata matematika materi pecahan sederhana masih rendah di SD Inpres 103 HBM Kota Sorong, yang terdapat pada kelas III A siswi 13 dan siswa 15 yang berjumlah 28. Mayoritas siswa kelas III masih kesulitan memahami materi pecahan sederhana dengan kompetensi dasar membandingkan pecahan sederhana.

Data tersebut terlihat dari ulangan harian matematika siswa kelas III A yang terdapat 28 siswa, dari nilai pengetahuan ada 13 siswa yang mendapatkan nilainya tidak mencapai KKM dengan nilai rendah 50 56, 11 siswa yang mencapai KKM dengan rentang nilai 60 - 75. Guru kelas III SD Inpres 103 HBM Kota Sorong menentukan nilai kriteria ketuntasan dengan KKM 60. Oleh karena itu peneliti menggunakan model pembelajaran yang membuat siswa menjadi lebih aktif agar hasil belajar siswa meningkat. Siswa harus diberikan kesempatan untuk menemukan sendiri konsep pembelajaran yakni Guided Inquiry Learning. Guided Inquiry Learning merupakan pembelajaran yang dimulai dengan memberikan pertanyaan kepada siswa untuk berkontribusi sendiri terhadap perkembangan pengetahuan yang dibutuhkan untuk menyelesaikan masalah.

Menerapkan Guided Inquiry Learning berarti suatu rangkaian kegiatan belajar yang melibatkan secara maksimal seluruh kemampuan siswa untuk mencari dan menyelidiki secara sistematis, kritis, logis, analitis, sehingga mereka dapat merumuskan sendiri penemuannya dengan penuh percaya diri. Metode inquiry adalah cara penyampaian bahan pengajaran dengan memberikan kesempatan kepada siswa untuk belajar mengembangkan potensi intelektualnya dalam jalinan kegiatan yang disusunnya sendiri untuk menemukan sesuatu sebagai jawaban yang menyakinkan 
terhadap permasalahan yang dihadapkan kepadanya, melalui proses pelacakan data dan informasi serta pemikiran yang logis, kritis ,dan sistematis. Tujuan Guided Inquiry Learning diperlukan untuk melihat Pengaruh hasil Belajar Matematika Pada Materi Operasi Pecahan Di Kelas III SD Inpres 103 HBM Kota Sorong.

Fahmia H., Karjiyati V., \& Dalifa, (2019) menjelaskan pembelajaran guided inquiry adalah pembelajaran yang berbasis inqury dalam proses pembelajaran, siswa tidak hanya duduk diam mendengarkan penyampaian materi dari guru, tetapi melakukan penemuan untuk menjawab permasalahan yang diajukan oleh guru, dimana dalam proses penemuan siswa mendapatkan bimbingan secara intensif. Proses pembelajaran bimbingan yang guru berikan kepada siswa berupa pertanyaanpertanyaan dan diskusi multiarah yang mengiring siswa agar bisa memahami konsep yang dipelajari.

Pembelajaran quided inquiry membuat siswa memiliki peluang besar untuk melakukan sebuah penemuan, sehingga siswa akan mendapatkan hasil dari materi yang mereka pelajari. Hal ini sependapat dengan Anam, (2015) menjelaskan tentang pembelajaran quided inquiry bahwa pemahaman siswa akan konsep dasar dan ide -ide menjadi lebih baik. Selain itu juga, Sanjaya, (2012) mengungkapkan juga bahwa salah satu kelebihan pembelajaran dengan menggunakan guided inquiry yaitu menjadikan pembelajaran lebih bermakna, karena mencangkup tiga aspek yaitu kognitif, afektif, dan psikomotor mengalami perkembangan secara seimbang. Hasil Belajar itu sendiri menurut Sudjana (2010) bermakna kemampuan yang dikuasai dan dimiliki siswa setelah memperoleh atau menerima pengalaman belajar. Dengan kata lain hasil belajar matematika menurut peneliti adalah kemampuan yang akan dimiliki siswa setelah mengikuti materi matematika. Sesuai dengan tujuan pembelajaran matematika, hasil belajar matematika yang akan sangat bermanfaat untuk siswa dalam mengembangkan potensi dirinya baik dari segi kognitif, afektif, maupun psikomotorik.

Ketidakberhasilan suatu proses belajar matematika menurut Muslina (2018), menjelaskan bahwa bukan hanya disebabkan matematika yang sulit, melainkan disebabkan oleh beberapa faktor yang meliputi siswa itu sendiri, guru, metode/media pembelajaran, maupun lingkungan belajar yang salingberhubungan satu sama lainya. Melvin (2017) Menyatakan bahwa hasil belajar tidak lain adalah hasil akhir dari proses belajar mengajar sebagai perwujudan segala upaya yang telah dilakukan selama proses berlangsung. Alman (2015) menjelaskan bahwa hasil belajar merupakan hal yang tidak dapat dipisahkan dari kegiatan belajar, karena kegiatan belajar merupakan proses kognitif yang dibutuhkan untuk mengetahui sesuatu yang di pelajari. Menurut Yunan (2015) hasil belajar adalah suatu penilaian akhir dari proses dan pengenalan yang telah dilakukan berulang-ulang, serta akan tersimpan dalam jangka waktu lama atau bahkan tidak akan hilang selama-lamanya karena hasil belajar turut serta dalam membentuk pribadi individu yang selalu ingin mencapai hasil yang lebih baik lagi sehingga akan merubah cara berpikir serta menghasilkan prilaku yang lebih baik.

Kunandar, (2013) menyebutkan bahwa beberapa karakteristik penilaian hasil belajar pada satuan pendidikan dasar adalah salah satu karakteristik tentang penilaian sebagai berikut: (a) Penilaian dilakukan secara utuh dan menyeluruh terhadap semua aspek pembelajaran, baik pengetahuan, keterampilan, maupun sikap/nilai, (b) Kegiatan penilaian harus sudah direncanakan bersamaan dengan kegiatan penyusunan program semester dan dilaksanakan sesuai dengan program yang telah disusun, (c) Penilaian dilakukan dengan mengacu pada indikator dari masing-masing kompetensi dasar dari setiap mata pelajaran, (d) Penilaian pembelajaran tematik mencakup penilaian terhadap proses dan hasil belajar siswa. Kunandar, (2013) juga mengatkan bahwa penilaian pembelajaran pada kurikulum 2013 menggunakan pendekatan penilaian acuan 
patokan dan ketuntasan belajar. Penilaian Acuan Patokan (PAP). Artinya semua kompetensi perlu dinilai dengan menggunakan acuan patokan berasarkan pada indikator hasil belajar.

Sekolah menetapkan acuan patokan sesuai dengan kondisi dan kebutuhannya. Seperti dikemukakan Mardapi, (2012:13) bahwa pada BAB X pada pasal 60 Peraturan Pemerintah No. 19 tahun 2005 dijelaskan bahwa penilaian pendidikan pada jenjang pendidikan dasar dan menengah yang terdiri atas: (a) penilaian hasil belajar oleh pendidik; (b) penilaian hasil belajar oleh satuan pendidikan; dan (c) penilaian hasil belajar oleh pemerintah. Selanjutnya dijelaskan pula bahwa pada pasal 64 bahwa penilaian hasil belajar oleh pendidik dilakukan secara berkesinambungan untuk memantau proses, kemajuan, perbaikan hasil dalam bentuk ulangan harian, ulangan tengah semester, ulangan semester, dan ulangan kenaikan kelas.

Hasil belajar siswa kelas III SD Inpres 103 HBM Kota Sorong, SD Inpres 103 HBM Kota Sorong pada pelajaran matematika belum sesuai dengan terhadap pembelajaran matematika masih kurang. Hal tersebut disebabkan oleh beberapa alasan, antara lain karena belajar matematika dirasakan sulit dan banyak guru dalam mengelola pembelajaran matematika dalam menyampaikan materi menggunakan metode yang kurang menarik sehingga siswa menjadi sulit dalam memahami pelajaran matematika yang dibawah guru pada materi operasi pecahan.

Pembelajaran diawali dengan pemberian pertanyaan mengenai masalah yang berhubungan dengan kehidupan sehari hari siswa yang berfungsi untuk merangsang pengetahuan awal siswa dan sebagai gambaran terhadap materi yang akan dipelajari. Oleh karena itu, peneliti tertarik untuk melakukan penelitian guna meningkatkan hasil belajar siswa kelas III SD Inpres 103 HBM Kota Sorong menggunakan model Matematika Guided Inquiry Learning pada materi pokok operasi hitung pecahan.Berikut ini bagian dari kerangka berpikir :

Kondisi Awal

Siswa kurang aktif dalam pembelajaran matematika materi operasi bilangan pecahan.

Menggunakan pendekatan Guided Inquiry Leaning dalam pembelajaran tentang operasi hitung bilangan pecahan

Hasil Belajar Operas bilangan pecahan

Memberikan pengaruh terhadap siswa aktif dalam pelajaran matematika materi operasi bilangan pecahan menggunakan model Guided Inquiry Learnng terhadap hasil belajar Operasi Bilangan pecahan di SD pres 103 HBM Kota Sorong

Gambar 1. Kerangka Berpikir

\section{METODE PENELITIAN}

Jenis penelitian yang digunakan peneliti yaitu penelitian pra-eksperimen dengan desain One-Shot Case Study. Dalam penelitian ini penelitimemberikan perlakuan alat peraga mobil garis bilangan lalu memberikan posttest. Sugiyono (2017) menggambarkan One-Shot Case Study design sebagai berikut:

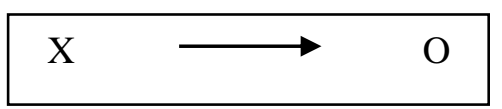

Gambar 2. Desain One Shot Case Study

$$
\begin{aligned}
& \mathrm{X}=\text { Perlakuan } \\
& \mathrm{O}=\text { Posttest (setelah diberi perlakuan) }
\end{aligned}
$$

Adapun teknik pengumpulan data yang digunakan adalah posttest. Posttest digunakan sebagai alat penilaian berupa pertanyaan-pertanyaan yang diberikan kepada siswa dengan maksud untuk 
mendapat jawaban dalam bentuk tes tertulis. Tes tertulis ini berjumlah 10 soal dalam bentuk soal pilihan ganda materi operasi bilangan pecahan yang nantinya akan digunakan untuk melihat pengaruh Guided Inquiry Learning Terhadap Hasil Belajar Siswa pada Materi Operasi Pecahan Di Kelas III SD Inpres 103 HBM Kota Sorong. Observasi dilakukan pada saat proses pembelajaran berlangsung dan juga keterlaksanaan pembelajaran dengan penggunaan alat peraga mobil garis bilangan. Observasi dilakukan oleh guru kelas dengan cara pengamatan mengenai pelaksanaan pembelajaran di dalam kelas yang melibatkan aktivitas guru dalam mengajar dengan menggunakan alat peraga mobil garis bilangan dalam proses pembelajaran serta observasi aktivitas belajar siswa selama proses pembelajaran berlangsung. Dokumen digunakan untuk mendapatkan data mengenai kegiatan yang terjadi selama pembelajaran berlangsung. Teknik ini lebih menjelaskan suasana yang terjadi dalam proses pembelajaran. Dokumentasi berupa foto dengan menggunakan camera HP untuk mengambil gambar siswa dalam proses belajar mengajar berlangsung di SD Inpres 103 HBM Kota Sorong.

\section{HASIL DAN PEMBAHASAN}

Penelitian ini menggunakan beberapa instrumen yakni observasi, posttes dan dokumentasi. Instrumen tes berupa posttest untuk mengumpulkan data hasil belajar matematika siswa kelas III. Posttest yang digunakan dalam bentuk tes pilihan ganda dengan materi operasi bilangan pecahan. Soal tes dalam posttest ini berjumlah 10 (sepuluh) soal pilihan ganda. Tes ini digunakan untuk melihat kondisi siswa yang ada di dalam kelas saat proses belajar mengajar. Data yang diperoleh dari hasil observasi aktivitas guru dalam proses pembelajaran matematika materi operasi bilangan pecahan berlangsung. Skala yang digunakan dalam penelitian adalah menggunakan penilaian skala Guttman, dimana skala ini hanya menginginkan jawaban Ya atau Tidak, dalam rangka tahapan penilaian proses belajar mengajar didalam kelas. Hasil posttest siswa berdasarkan frekuensi yang meningkat dengan hasil belajar yang dilakukan sesuai dengan data hasil posttest berikut:

Tabel 1. Tabel Distribusi Frekuensi Soal Posttes

\begin{tabular}{cccc}
\hline Nilai & \multicolumn{3}{c}{ Frekuensi } \\
& Batas Kelas & Kumulatif & Relatif \% \\
\hline $41-45$ & $59,5-65,5$ & 4 & 15 \\
$46-50$ & $65,5-70,5$ & 9 & 30 \\
$52-54$ & $70,5-75,5$ & - & - \\
$55-59$ & $75,5-80,5$ & 9 & 30 \\
$81-85$ & $80,5-85,5$ & - & - \\
$86-90$ & $85,5-90,5$ & 5 & 25 \\
\hline
\end{tabular}

Berdasarkan data pada tabel 1 di atas menunjukkan bahwa banyaknya kelas ada 6 dengan panjang tiap interval kelas adalah 5 . Nilai yang paling banyak diperoleh siswa terletak pada interval 66-70 dan 76-80 yaitu sebesar $30 \%$ (9 orang dari 28 siswa). Sedangkan nilai yang paling sedikit diperoleh terletak pada interval 40-45 yaitu sebesar $15 \%$ (4 orang dari 28 siswa). Nilai rata-rata yang diperoleh dari pretes ini adalah 76,78 .

Uji normalitas digunakan untuk menguji data apakah berdistribusi normal atau tidak.Untuk menguji normalitas peneliti menggunakan rumus kolmogorovsmirnov.Pengujian normalitas dilakukan terhadap hasil belajar prettest dan posttest siswa. Berikut hasil uji normalitas yang diperoleh dari pengolahan data hasil belajar.

Tabel 2. Uji Normalitas Kolmogorov Smirnov

\begin{tabular}{rcrr}
\hline Jenis Tes & Asymp. Sig & A & Keterangan \\
Posttest & 0121 & 0,05 & $0,121>0,05$ \\
\hline
\end{tabular}

Berdasarkan tabel di atas yang diperoleh dari perhitungan dengan menggunakan software statistik diketahui hasil belajar posttest siswa kelas III memiliki taraf signifikansi 0,1200>0,05sehinggadapat disimpulkan bahwa kelas VI sebagai kelas berdistribusi normal. Dapat disimpulkan bahwa data dalam penelitian memiliki varian yang sama, dan data layak digunakan untuk uji selanjutnya, yaitu uji hipotesis 
Setelah uji prasyarat (uji normalitas) terpenuhi, maka selanjutnya adalah uji hipotesis.Dalam penelitian ini untuk pengujian hipotesis peneliti menggunakan uji $\mathrm{t}$ atau biasa disebut $\mathrm{t}$ - test. Uji hipotesis dilakukan dengan cara yaitu menggunakan software statistik. Hasil uji one sample t-test adalah sebagai berikut.

Tabel 3. Uji One Sample T-test

\begin{tabular}{cccc}
\hline & T & df & Sig. (2 tailed) \\
\hline Postest & 3.712 & 22 & .001 \\
\hline
\end{tabular}

Pada pengujian hipotesis di atas dengan menggunakan uji -t test one sample test karena hanya terdapat satu varian dimana data yang diuji yaitu hasil posttest berdasarkan hasil perhitungan maka diperoleh thitung sebesar 3.712 dengan $\mathrm{dk}=$ $\mathrm{n}-1(23-1=22)$ diperoleh ttabel sebesar8.953 dengan $\mathrm{dk}=\mathrm{n}-1(28-1=27)$ diperoleh ttabel sebesar 1.915. Berdasarkan hasil analisis data yaitu nilai thitung $>$ ttabel $(8.953>1.703)$, dengan besarnya taraf signifikansi 0.05 , yakni $(0.000<0.05)$ maka Hipotesis diterima, berarti dapat disimpulkan bahwa terdapat Pengaruh Quided Inquiry Learningterhadap Hasl Belajar Matematika Terhadap Materi Operasi Pecahan di Kelas III SD Inpres 103 HBM Kta Sorong.

Hasil penelitian ini bisa di katakan sama atau berhasil dilakukan oleh peneliti dengan di dukung oleh penelitian terdahulu yaitu Hasil penelitian ini bisa di katakan sama atau berhasil dilakukan oleh peneliti dengan di dukung oleh penelitian terdahulu yaitu penelitian yang dilakukan oleh Fajar Triyanto, Joko Siswanto dan Rofian tahun 2018 yang berjudul Keefektifan Media Pembelajaran Mogabil Terhadap Hasil Belajar Matematika Siswa Kelas IV SDN 02 Baleraksa Purbalingga yang menyimpulkan bahwa alat quided nquiry learning (operasi bila- ngan) efektif terhadap hasil belajar matematika materi operasi hitung bilangan siswa. Hal ini dapat dilihat pada analisis uji hipotesis untuk menguji efektif atau tidaknya alat peraga Mobil Garis Bilangan terhadap hasil belajar diperoleh bahwa hasil post-test lebih tinggi dibanding hasil uji t diperoleh thitung > ttabel yaitu 15,360 > 2,048 maka H0 ditolak dan Ha diterima.

Dari hasil pengujian data di atas, peneliti dapat menyimpulkan bahwa dari penelitian yang dilakukan di peroleh hasil bahwa terdapat pengaruhguided inquiry learning terhadap hasil belajar atematika pada siswa materi operasi pecahan kelas III SD Inpres 103 HBM Kota Sorong.

\section{KESIMPULAN}

Berdasarkan rumusan masalah dan hipotesis yang diajukan, serta hasil penelitian yang didasarkan pada analisis data dan pengujian hipotesis, maka kesimpulan yang dapat dikemukakan dalam penelitian ini yaitu terdapat pengaruh yang signifikan pada Pegaruh Guided Inquiry Learning Terhadap Hasil Belajar Matematika Siswa Pada Materi Operasi Pecahan Di Kelas III SD Inpres 103 HBM Kota Sorong pada Tahun Ajaran 2019/2020. Hal ini ditunjukan nilaithitung= 8.953, sedangkan ttabel pada taraf signifikasi $5 \%$ adalah 1.703 , Karena thitung $>$ ttabel maka Hipotesis diterima.

\section{DAFTAR RUJUKAN}

Alman, (2015). Perbedaan Pengaruh Metode Open Ended Dengan Metode Stad Terhadap Kemampuan Pemecahan Masalah Matematika Peserta Didik Kelas V SD Negeri Serayu Yogyakarta Ditinjau Dari Prestasi Belajar. Tesis. tidak diterbitkan: Yogyakarta.

Anam, K. 2015. Pembelajaran Berbasis Inkuiri. Yogyakarta: Pustaka Pelajar.

Fahmia H., Karjiyati V., \& Dalifa, (2019). Pengaruh Model Guided Inquiry Terhadap Hasil Belajar Siswa Pada Pembelajaran Matematika Siswa SD Kota Bengkulu. Jurnal Riset Pendidikan Dasar, 2 (3) : 237 - 244.

Kunandar. (2013). Penilaian Autentik: Penilaian Hasil Belajar Peserta Didik Berdasarkan Kurikulum 2013, Suatu Pendekatan Praktis. Rajawali Pres: Jakarta.

Mardapi, Djemari. (2012). Pengukuran 
Penilaian \& Evaluasi Pendidikan. Nuha Litera: Yogyakarta.

Muslina, (2018). Peningkatan Hasil Belajar Matematika Siswa Kelas II SD Melalui Model Pembelajaran Kooperatif Tipe Student Team Achievement Division. Jurnal Cendekia: Jurnal Pendidikan Matematika, Volume 2, No. 2, Agustus 2018, hal. 111 -117.

Sanjaya. 2012. Strategi Pembelajaran Berorientasi Standar Proses Pendidikan. Jakarta: Kencana Prenada Media Group.

Sofiana, (2015). Peningkatan Hasil Belajar Operasi Hitung Bilangan Pecaan Melalui Pendekatan Matematika Realistik Pada Siswa Kelas V SD NEGERI 3 GRENGGENG 2015. Skripsi. Tidak Diterbitkan. Grengeng.
Sugiyono, (2017). Metode Penelitian Kuantitatif, Kualitatif dan $R \& D$. Alfabeta: Bandung.

Sudjana, Nana. (2010). Penilaian Hasil Proses Belajar Mengajar. Remaja Rosdakarya: Bandung.

Tria Melvin, (2017). Hubungan Antara Disiplin Belajar Di Sekolah Dengan Hasil Belajar Gegrafi Pada Siswa Kelas X sma Negeri 10 Kendari, 1(1), (2017), 1-14.

Yunan, (2015). Upaya Meningkatan Hasil Belajar Siswa pada Mata Pelajaran PAI dalam Mengenal Malaikat dan Tugasnya Melalui Metode Make a Match di Kelas IV SD Negeri 103 Palembang. Skripsi. tidak diterbitkan. Palembang. 